\title{
Biomarkers in Solid Organ Transplantation
}

John Choi, MD, Albana Bano, MD, and Jamil Azzi, MD*

Transplantation Research Center, Renal Division, Brigham and Women's Hospital, Harvard Medical School, 221 Longwood Avenue, Boston, MA 02115, USA

\section{Keywords}

Transplant; Biomarker; Allograft; Rejection; Transplant immunology

\section{INTRODUCTION}

Since the first human kidney transplant in $1954,{ }^{1}$ transplantation has expanded to various organs including heart, lung, liver, pancreas, and even vascularized composites (limbs and face). The outcome for each organ clearly supports the transplantation to be the best management option. Transplantation improves quality of life and is cost effective when compared with other supportive options in end organ diseases ${ }^{2-12}$; more important, it is a life-saving event.

A number of challenges remain, despite the promising data and achievements in organ transplantation. One of the most striking facts is the lack of advancement in long-term graft survival. ${ }^{13}$ Although the 1-year survival in kidney transplant recipient has significantly improved between 1989 and 2008, the long-term graft survival did not show much improvement. Although this finding may be attributable to an increased number of higher risk profile donors and recipients in the pool, it underscores the lack of biological and clinical knowledge in long-term graft management. Another concern is the aggravating organ shortage to accommodate increased demand. Based on Organ Procurement and Transplantation Network data as of January 2018, number of patients awaiting organ transplantation has exceeded 110,000 in the United States. Last but not least, the number of therapeutic agents used in transplantation, mainly the immunosuppressive regimen, has been relatively stagnant over past decades. ${ }^{14}$ To overcome such challenges, there has been increasing interest in developing novel biomarkers that can guide risk assessment, prognostication, and management.

Recapitulating specific aims in transplantation can help with the systematic categorization of biomarkers. Some of the main goals of transplantation include (1) optimizing allograft and living donor assessment, (2) advancing matching algorithm and immunologic risks evaluation, (3) improving allograft survival, and (4) minimizing unintended side effects from the immunosuppressive regimen. Although certain biomarkers may reveal useful information in multiple domains, a judicious combination of tests is crucial for successful

*Corresponding author. jazzi@ rics.bwh.harvard.edu. 
outcomes. In this review, we explore the laboratory process and clinical application of selective biomarkers. Finally, we introduce novel biomarkers that were recently discovered and are undergoing validation.

\section{INTRODUCTION OF BIOMARKERS IN SOLID ORGAN TRANSPLANTATION}

A biomarker is defined as "a characteristic that is, objectively measured and evaluated as an indicator of normal biological processes, pathogenic processes, or pharmacologic responses to a therapeutic intervention." 15 An ideal biomarker should provide an accurate assessment of the disease status and provide predictive and prognostic value. It should be easy to collect, simple to run the assay, and provide results efficiently and cost effectively.

There is an interesting story behind the first biomarker tested in solid organ transplantation. Before laboratory tests were available to measure alloimmunity in preparation for kidney transplants, full-thickness skin grafts were exchanged between the donor and the recipient to test tissue compatibility. ${ }^{1}$ After confirming that there was no evidence of skin graft rejection, Murray and colleagues ${ }^{16}$ proceeded with the transplant, and validated the successful graft acceptance. A few years after the first kidney transplant, Patel and colleagues ${ }^{17}$ discovered the risk of allograft hyperacute rejection associated with the cytotoxicity of recipient serum (containing antidonor antibody) on donor cells. This revolutionary method is now called a microcytotoxicity test and is the basis for different tests performed in the laboratory. Since then, a number of powerful assays have been introduced for donor-recipient matching and posttransplant management.

\section{TISSUE TYPING AND CROSS-MATCH}

During the pretransplantation evaluation, a series of critical tests are performed at the tissue typing laboratory. The assessment begins with the HLA typing of both the donor and the recipient. Luminex reverse polymerase chain reaction sequence-specific oligonucleotide has been a popular method for HLA typing. The Luminex system is based on internally colorcoded beads that are in turn coated with various sequence-specific oligonucleotide probes that bind target HLA alleles. When DNA binds, it is subsequently labeled with streptavidin conjugated with R-phycoerythin. Flow cytometry can identify the bead and the presence of amplicon of specific allele as a final read out based on the intensity and characteristics of the signal. Although the resolution for typing is generally lower than that with other techniques such as the sequence-specific primers method or sequence-based typing, polymerase chain reaction sequence specific oligonucleotide is widely accepted as standard practice owing to its simplicity and reproducibility. HLA typing by real-time polymerase chain reaction is more recently becoming a method of choice in several tissue typing laboratories as well.

The more powerful application of the Luminex bead platform is the detection of antibodies circulating in the recipient. The presence of donor-specific antibodies (DSA) correlates with allograft rejection and failure. ${ }^{18-20}$ In this US Food and Drug Administration-approved test, the color-coded bead is coated with HLA molecules and incubated with the subject's serum. Anti-IgG antibody conjugated with phycoerythin is then used as a secondary antibody for read out. The Luminex-based solid phase antibody screen has revolutionized the field, 
because the information can be registered in United Nation of Organ Sharing's online database system, UNet, for virtual cross-matching. Virtual cross-matching, compared with manual wet cross-matching, drastically decreases the time taken and increases the chance of identifying the best match of candidates with available donors. Virtual matching is essentially an assessment of compatibility of donor and recipient based on a paper report on antigens of the donor and antibodies of the potential recipient. This approach is useful in case of import donors, when the time to perform a wet cross-match is usually not there. Solid phase antibody assay is also performed posttransplantation for de novo DSA surveillance. There are caveats to this assay, because not all antibodies exercise cytotoxicity.

Microcytotoxicity, as discussed elsewhere in this article, is an example of a screening tool for clinically relevant DSA. This discovery has been used for many decades in a format of complement-dependent cytotoxicity, which uses rabbit complement to target donor cellbound antibodies. However, owing to its technical complexity as well as its suboptimal sensitivity and specificity, series of modifications were made on the Luminex-based solid phase assays. Currently, the C1q assay is a popular assay of choice for detecting complement binding anti-HLA antibodies in patient serum. ${ }^{21}$ This flow cytometry-based assay quantifies the recipient's C1q bound to antibodies linked to the donor cell to infer the ability of initiating the classical pathway. Complement-binding antibodies as detected by C1q assay or by other means show higher correlation for acute rejection, antibody-mediated rejection, transplant glomerulopathy, and graft failure when compared with C1q nonbinding DSA. $^{22,23}$ In general, it has been shown that high titered antibodies are usually complement binding; this is due to the fact that a high molar amount of antibody is required to recruit complement to mediate cytotoxicity. Not only donor-specific-IgG antibodies, but also donor cell-binding IgM antibodies can be detected with this assay. Although this may be viewed as suboptimal specificity, DSA IgG-negative/IgM-positive patients were found to have antibody-mediated rejection with future development of DSA IgG, suggesting the clinical significance of IgM binding. ${ }^{24}$

\section{ADDITIONAL RISK ASSESSMENT TOOLS}

Advances in technology and accumulating data enabled the matching of donors and recipients at the level of epitopes for each of the HLA molecules. Using 3-dimensional modeling, a computer program from the database (HLAMatchmaker) can identify alloantigenic eplets when the high-resolution (4-digit) HLA genotype is provided. Studies have shown an association between degree of epitope mismatch to corresponding risk of antibody-mediated rejection. ${ }^{25-28}$ With a dramatic decrease in sequencing cost, epitope matching may become a standard practice in the near future.

Increasing evidence is reported on critical role of non-HLA antibodies in transplantation. ${ }^{29,30}$ A number of non-HLA molecules expressed on the allograft display polymorphisms thereby priming the recipient's B cells for alloantibody production in a stressed environment. ${ }^{30,31}$ In addition to these non-HLA molecules from the allograft, previously unexposed self-antigens may be uncovered in the setting of inflammation and increase the probability of development of autoantibodies. These antibodies are clinically associated with a higher risk for hyperacute rejection, short-term graft survival, and antibody-mediated 
rejection. ${ }^{32-38}$ Since the report of antiendothelial cell antibodies, ${ }^{32}$ multiple important nonHLA antibodies have been identified. Major histocompatibility class 1-related chain A antigens that share the major histocompatibility locus have been well-described as being related to an increased risk for kidney allograft failure. ${ }^{39}$ The presence of anti-major histocompatibility class 1-related chain A antigen antibodies can be tested on a Luminexbased platform. The antiangiotensin type II receptor, which is also associated with an increased risk of recurrent focal segmental glomerulosclerosis, ${ }^{40-42}$ can be tested with an enzyme-linked immunosorbent assay. Although these panels are not routinely tested at this time, assays are available at selective transplant centers.

\section{BIOMARKERS FOR ALLOGRAFT MONITORING}

Currently available noninvasive tests are generally not able to detect early allograft dysfunction and discriminate rejection from other types of allograft injury. For example, a change in the serum creatinine level is the prototypical alarm for kidney allograft injury to prompt further investigation. Unfortunately, creatinine remains relatively stable until significant damage occurs (not sensitive), and can be increased owing to multiple possible etiologies (not specific). ${ }^{43,44}$ In most cases, when clinicians cannot rule out rejection, only a few options are available: an antibody panel to check DSA and a biopsy for histopathology. 45,46 Biopsies have been the gold standard for diagnosing rejection, although the paradigm has been focused on developing accurate noninvasive biomarkers. The approach for identifying a noninvasive biomarker is appealing, because it will minimize the risk and resources associated with biopsying an organ in case of a suspected rejection. ${ }^{47-51} \mathrm{In}$ addition, novel biomarkers may help to classify different forms of rejection on a molecular basis that will assist in formulating the most effective treatment. ${ }^{52}$ In the following paragraphs, we introduce some of the biomarkers that have passed various stages of validation phases. In addition, we briefly discuss potential preclinical studies that may have implications for future biomarker development.

Urine is an attractive source for biomarker mining owing to its ability to be collected conveniently. Urinary biomarkers have high potentials for translation through a longitudinal monitoring method. In addition, the composition is directly affected by graft function in kidney transplantation. One of the most well-validated, noninvasive rejection markers is the urine messenger RNA study by Suthanthiran and Muthukumar. ${ }^{53}$ The group isolated RNA from urine cell pellets and tested messenger RNA level of CD3 $\varepsilon$ and IP-10 with 18S rRNA, markers that distinguished acute cellular rejection from antibody-mediated rejection and borderline rejection. In addition, the signature urinary messenger RNA were elevated before the detection of biopsy-proven rejection, which showed that these markers were predictive. This was a multicenter study through clinical trials in organ transplantation (CTOT-04) consortium, which strengthens the reproducibility.

Urinary proteins were also tested as potential biomarkers. Because chemokines are essential in recruiting inflammatory cells, ${ }^{54}$ CXCR3-binding protein CXCL9, and CXCL10 were identified as correlated with allograft rejection. ${ }^{55,56}$ Bead-based techniques can be applied again for urinary protein detection, by coating them with antibodies for proteins of interest. Follow-up studies further confirmed the role of CXCL9 in discriminating acute T-cell- 
mediated rejection and CXCL10 in antibody-mediated rejection. ${ }^{57-60}$ The limitation with urinary chemokines was their inability to distinguish between allograft rejection and BK nephropathy. ${ }^{57}$

The microarray is another attractive platform for testing multiple signature transcriptions and has been mainly used with biopsy samples. A few years ago the molecular diagnostic system was introduced to evaluate the allograft biopsy samples at a gene expression level. ${ }^{61}$ This assay interrogated the current limitation with morphology-based diagnosis of acute cellular rejection and antibody-mediated rejection. The group further tested microarray system in a multicenter, large cohort and showed correlations between the selected pathogenesis-based transcript sets and their associated diagnosis showing its superior diagnostic resolution and predictive power compared with the current histopathologic diagnosis. ${ }^{62,63}$ The Genomics of Chronic Allograft Rejection (GoCAR) study ${ }^{64}$ is another example of a microarray based biomarker discovery, where authors from multiple centers extracted RNA from frozen biopsy samples and tested the differential expression of 13 different genes, and showed a correlation with kidney fibrosis development. The main goals of microarray-based systems are to identify subclinical, at-risk groups and prevent the progression of allograft failure and fibrosis.

A donor-derived cell-free DNA kit (CareDx, Inc., Brisbane, CA) is another ground-breaking technique that has been introduced to the biomedical field. Previously, cell-free DNA has been well-described in fetomaternal genetics and lately in oncology as a novel tool for monitoring circulating tumor signal. The introduction of next-generation sequencing was key to the momentum of this platform ${ }^{65}$ because the cost and time necessary for the assay has now become clinically relevant. In this assay, the donor-derived cell-free DNA detects the frequency of donor single nucleotide polymorphisms and this has been shown to be an effective assay to discriminate rejection in multiple systems. such as the kidney, pancreas, liver, heart, and lung. ${ }^{66-71}$ It also showed a predictive value as the level was elevated months before a biopsy-proven rejection event. ${ }^{71}$

Finally, our group developed a platform, an integrated kidney exosomes analysis to rapidly detect kidney allograft rejection with high accuracy using urine sample. ${ }^{72}$ Extracellular vesicles facilitate intercellular communication and play a critical role in transplant immunology. As T cells infiltrate kidney tubules during acute cellular rejection, exosomes are shed into tubular lumen with signature membrane protein from parent T cell (CD3 in our study). T-cell extracellular vesicles in urine samples are enriched with magnetic beads coated with anti-CD3 antibody. Captured extracellular vesicles are then labeled with horseradish peroxidase conjugated anti-CD63 antibody, which is a marker used to identify exosomes. For read out, the complex is mixed with a chromogenic electron mediator to generate measurable electronic current. Currently, a multicenter prospective study is being conducted to test the predictive value of this assay in a large cohort of patients.

\section{BIOMARKERS FOR IMMUNE MONITORING}

Transplant recipients suffer from infection and malignancy, which stems from the toxicity of long-term immunosuppressive regimens. ${ }^{73}$ Clinical trials were conducted to test the safety of 
immunosuppression withdrawal in hope of minimizing the burden of potent medications; so far, withdrawal was shown to be associated with increased risk of rejection and allograft failure. ${ }^{74,75}$ One's immunosuppression regimen is currently managed according to each center's protocol in an effort to reflect immunologic risks specific to each institution's patient population. In particular, the calcineurin inhibitor, the central component of an immunosuppressive regimen, is titrated based on the serum trough level. ${ }^{76}$ However, the target level does not reflect the individual's immune system leading to overimmunosuppression or underimmunosuppression. There are limited methods with which to test immune cell function; therefore, there is an increasing demand for the development of a novel immune monitoring platform.

Interferon (IFN)- $r$ enzyme-linked immunosorbent spot (ELISPOT) is tested to infer the donor memory T-cell activity. The assay quantifies IFN- $r$ production by mixing isolated recipient memory T cells to donor cells. ${ }^{77}$ Elevated IFN- $r$ production correlates with an increased risk of developing acute cellular rejection and having progressive allograft failure. 78-80 The limitation has been intercenter variation, partly owing to the variation in induction therapy ${ }^{81}$ and the technical complexity for standardization. ${ }^{78}$ Further optimization with a panel of reactive $\mathrm{T}$ cells in place of donor cells, which is often inaccessible after transplantation, and may enhance the usefulness of the ELI-SPOT assay.

When overimmunosuppression is suspected, a US Food and Drug Administration-approved (ViraCor-IBT, Immuknow, Lee's Summit) assay can provide insight on the recipient's immune function. ${ }^{82}$ The Immuknow assay exploits the T-cell production of ATP by antigen presentation. $\mathrm{CD}^{+} \mathrm{T}$ cells isolated from the recipient's peripheral blood mononuclear cells are stimulated with mitogen. The induced intracellular ATP level is then measured in a luminometer after adding luciferin/luciferase mixture. A low level of ATP correlates with overimmunosuppression and infections. ${ }^{83-86}$ In addition, a single-center, randomized, controlled trial on a liver transplant recipient showed improved allograft survival rate with Immuknow-assisted titration of immunosuppressive regimen. ${ }^{87}$ However, different studies failed to prevent rejection based on Immuknow, suggesting technical difficulties with standardizing the test. ${ }^{84-86,88}$

Although current immune monitoring assays stem from T-cell biology, increasing attention has been focused on B-cell function, which is directly linked with acute and chronic antibody-mediated injury. ${ }^{89}$ Quantifying DSA generating B-cell function, especially memory B-cell function, may be a sensitive method to predict future antibody production and chronic graft failure. ${ }^{90} \mathrm{HLA}$-specific B-cell clones can be detected by HLA tetramer staining, and these B-cell clone frequencies correlated with future DSA detection. ${ }^{91-93}$ It is worth mentioning that ELISPOT, which is currently used for memory T-cell function, was initially introduced for B-cell clone detection. ${ }^{94}$ Studies have shown the feasibility of detecting DSA-producing B-cell clone with ELI-SPOT. ${ }^{95,96}$ Although limitations with clinical translation are expected owing to the rarity and bias in the circulating memory B-cell population, ${ }^{97-99}$ functional B-cell monitoring will become an essential biomarker in the near future in conjunction with advancement in B-cell biology. 


\section{DONOR CANDIDATE AND ALLOGRAFT QUALITY ASSESSMENT}

The accurate assessment of allograft quality during organ procurement and the living donor candidate assessment are essential steps that can affect the expanding donor pool and safety of living donors. At present, assessment is heavily based on crude clinical data, including demographics, medical conditions, cause of death (for deceased donor), candidate allograft function, ischemia time, and postprocurement biopsy on high-risk allografts. However, novel molecular tests are also available to assist risk assessments.

Concern among the transplant community has increased because an increased risk of endstage renal disease and hypertension was detected in black donors. ${ }^{100,101}$ The APOL1 gene variant has been on spotlight as a causal polymorphism for the high frequency of chronic renal failure among African Americans. ${ }^{102}$ The presence of 2 high-risk APOL1 alleles has been associated with increased risk of focal segmental glomerulosclerosis and end-stage renal disease. ${ }^{103,104}$ Allografts from APOL1 high-risk donors showed a higher frequency of collapsing focal segmental glomerulosclerosis, ${ }^{105}$ and young African American donors carrying 2 high-risk APOL1 alleles were identified as the highest risk group for developing chronic kidney disease. ${ }^{106}$ Recently, a study was conducted to stratify the donor outcome among black living kidney donors with varying number of high-risk alleles. ${ }^{107}$ The study revealed the association of high-risk APOL1 genotype and accelerated estimated glomerular filtration rate loss in donors and is expected to be followed by a large cohort prospective study (APOLLO study). Although there is no current guideline regarding whether or not the APOL1 genotype should be tested routinely, our center counsels on the potential implication of high-risk variation to at-risk group donor candidates while making decision on proceeding with a genetic test. Further study results will guide generating consensus among the transplant society. ${ }^{108}$

\section{SUMMARY}

Owing to the complex medical conditions in patients with end-organ disease and the convoluted nature of alloimmunity, biomarkers serve a critical role in transplant medicine. Perhaps we are witnessing the most exciting time in transplant biomarkers-a number of promising biomarkers are being examined at different validation phases and are being introduced in everyday practice, awaiting wide implementation. The discovery of candidate biomarkers has accelerated as a result of advances in science and technology. Examples shared in this review include the donor-derived cell-free DNA test and the APOL1 gene test that would have been impossible without the innovation in sequencing. High-throughput analysis such as single cell analysis ${ }^{109}$ and the -omics approach ${ }^{110}$ opened a door to discover biomarkers through a hypothesis-generating fashion that complements traditional hypothesis-based experiments. It is imperative for researchers, clinicians, industrial, and administrative bodies to continue to work hand in hand to design an efficient pipeline of biomarkers to address unmet needs for patients.

\section{Acknowledgments}

Disclosure Statement: Funding support was provided by NIH grants to the authors Dr.Choi T32DK007527 and Dr. Azzi R01AI134842 and the author Dr. Bano have no disclosure. 


\section{REFERENCES}

1. Merrill JP, Murray JE, Harrison JH, et al. Successful homotransplantation of the human kidney between identical twins. JAMA 1956;160(4):277-82.

2. Wood RP, Ozaki CF, Katz SM, et al. Liver transplantation. The last ten years. Surg Clin North Am 1994;74(5):1133-54. [PubMed: 7940065]

3. Annual data report of the US Organ Procurement and Transplantation Network (OPTN) and the scientific registry of transplant recipients (SRTR). Introduction. Am J Transplant 2013;13(Suppl 1): 8-10. [PubMed: 23237694]

4. Large SR, English TA, Wallwork J. Heart and heart-lung transplantation, Papworth Hospital, 19791989. Clin Transpl 1989;73-8. [PubMed: 2487626]

5. O'Brien BJ, Buxton MJ, Ferguson BA. Measuring the effectiveness of heart transplant programmes: quality of life data and their relationship to survival analysis. J Chronic Dis 1987;40(Suppl 1):137S58S. [PubMed: 3298303]

6. Lough ME, Lindsey AM, Shinn JA, et al. Life satisfaction following heart transplantation. J Heart Transplant 1985;4(4):446-9. [PubMed: 3916519]

7. Bunzel B, Grundbock A, Laczkovics A, et al. Quality of life after orthotopic heart transplantation. J Heart Lung Transplant 1991;10(3):455-9. [PubMed: 1854773]

8. Russell JD, Beecroft ML, Ludwin D, et al. The quality of life in renal transplantation-a prospective study. Transplantation 1992;54(4):656-60. [PubMed: 1412757]

9. Witzke O, Becker G, Franke G, et al. Kidney transplantation improves quality of life. Transplant Proc 1997;29(1-2):1569-70. [PubMed: 9123428]

10. Starzl TE, Koep LJ, Schroter GP, et al. The quality of life after liver transplantation. Transplant Proc 1979;11(1):252-6. [PubMed: 377639]

11. Colonna JO 2nd, Brems JJ, Hiatt JR, et al. The quality of survival after liver transplantation. Transplant Proc 1988;20(1 Suppl 1):594-7. [PubMed: 3279651]

12. Bravata DM, Olkin I, Barnato AE, et al. Health-related quality of life after liver transplantation: a meta-analysis. Liver Transpl Surg 1999;5(4):318-31. [PubMed: 10388505]

13. Lamb KE, Lodhi S, Meier-Kriesche HU. Long-term renal allograft survival in the United States: a critical reappraisal. Am J Transplant 2011;11(3):450-62. [PubMed: 20973913]

14. Stegall MD, Morris RE, Alloway RR, et al. Developing new immunosuppression for the next generation of transplant recipients: the path forward. Am J Transplant 2016;16(4):1094-101. [PubMed: 26730885]

15. Biomarkers Definitions Working Group. Biomarkers and surrogate endpoints: preferred definitions and conceptual framework. Clin Pharmacol Ther 2001; 69(3):89-95. [PubMed: 11240971]

16. Murray JE, Hills W. The first successful organ transplants in man. JACS 2005; 200(1):5-9.

17. Patel R, Terasaki PI. Significance of the positive crossmatch test in kidney transplantation. N Engl J Med 1969;280(14):735-9. [PubMed: 4886455]

18. Lefaucheur C, Loupy A, Hill GS, et al. Preexisting donor-specific HLA antibodies predict outcome in kidney transplantation. J Am Soc Nephrol 2010;21(8): 1398-406. [PubMed: 20634297]

19. Mao Q, Terasaki PI, Cai J, et al. Extremely high association between appearance of HLA antibodies and failure of kidney grafts in a five-year longitudinal study. Am J Transplant 2007;7(4):864-71. [PubMed: 17391129]

20. Wiebe C, Gibson IW, Blydt-Hansen TD, et al. Evolution and clinical pathologic correlations of de novo donor-specific HLA antibody post kidney transplant. Am J Transplant 2012;12(5):1157-67. [PubMed: 22429309]

21. Chen G, Tyan DB. C1q assay for the detection of complement fixing antibody to HLA antigens. Methods Mol Biol 2013;1034:305-11. [PubMed: 23775744]

22. Chin C, Chen G, Sequeria F, et al. Clinical usefulness of a novel C1q assay to detect immunoglobulin $\mathrm{G}$ antibodies capable of fixing complement in sensitized pediatric heart transplant patients. J Heart Lung Transplant 2011;30(2):158-63. [PubMed: 20951058] 
23. Yabu JM, Higgins JP, Chen G, et al. C1q-fixing human leukocyte antigen antibodies are specific for predicting transplant glomerulopathy and late graft failure after kidney transplantation. Transplantation 2011;91(3):342-7. [PubMed: 21116220]

24. Chen G, Sequeira F, Tyan DB. Novel C1q assay reveals a clinically relevant subset of human leukocyte antigen antibodies independent of immunoglobulin $\mathrm{G}$ strength on single antigen beads. Hum Immunol 2011;72(10):849-58. [PubMed: 21791230]

25. Duquesnoy RJ, Takemoto S, de Lange P, et al. HLAmatchmaker: a molecularly based algorithm for histocompatibility determination. III. Effect of matching at the HLA-A,B amino acid triplet level on kidney transplant survival. Transplantation 2003;75(6):884-9. [PubMed: 12660519]

26. Lim WH, Wong G, Heidt $S$, et al. Novel aspects of epitope matching and practical application in kidney transplantation. Kidney Int 2018;93(2):314-24. [PubMed: 29061333]

27. Sypek M, Kausman J, Holt S, et al. HLA epitope matching in kidney transplantation: an overview for the general nephrologist. Am J Kidney Dis 2018;71(5): 720-31. [PubMed: 29246419]

28. Wiebe C, Pochinco D, Blydt-Hansen TD, et al. Class II HLA epitope matching-A strategy to minimize de novo donor-specific antibody development and improve outcomes. Am J Transplant 2013;13(12):3114-22. [PubMed: 24164958]

29. Li L, Wadia P, Chen R, et al. Identifying compartment-specific non-HLA targets after renal transplantation by integrating transcriptome and "antibodyome" measures. Proc Natl Acad Sci U S A 2009;106(11):4148-53. [PubMed: 19251643]

30. Opelz G, Collaborative Transplant Study. Non-HLA transplantation immunity revealed by lymphocytotoxic antibodies. Lancet 2005;365(9470):1570-6. [PubMed: 15866311]

31. Terasaki PI. Deduction of the fraction of immunologic and non-immunologic failure in cadaver donor transplants. Clin Transpl 2003;449-52. [PubMed: 15387129]

32. Brasile L, Rodman E, Shield CF 3rd, et al. The association of antivascular endothelial cell antibody with hyperacute rejection: a case report. Surgery 1986; 99(5):637-40. [PubMed: 3518110]

33. Harmer AW, Haskard D, Koffman CG, et al. Novel antibodies associated with unexplained loss of renal allografts. Transpl Int 1990;3(2):66-9. [PubMed: 2206221]

34. Jackson AM, Kuperman MB, Montgomery RA. Multiple hyperacute rejections in the absence of detectable complement activation in a patient with endothelial cell reactive antibody. Am $\mathbf{J}$ Transplant 2012;12(6):1643-9. [PubMed: 22300445]

35. Jordan SC, Yap HK, Sakai RS, et al. Hyperacute allograft rejection mediated by anti-vascular endothelial cell antibodies with a negative monocyte crossmatch. Transplantation 1988;46(4):5857. [PubMed: 3051566]

36. Niikura T, Yamamoto I, Nakada Y, et al. Probable C4d-negative accelerated acute antibodymediated rejection due to non-HLA antibodies. Nephrology (Carlton) 2015;20(Suppl 2):75-8. [PubMed: 26031592]

37. Sumitran-Karuppan S, Tyden G, Reinholt F, et al. Hyperacute rejections of two consecutive renal allografts and early loss of the third transplant caused by non-HLA antibodies specific for endothelial cells. Transpl Immunol 1997;5(4):321-7. [PubMed: 9504155]

38. Perrey C, Brenchley PE, Johnson RW, et al. An association between antibodies specific for endothelial cells and renal transplant failure. Transpl Immunol 1998; 6(2):101-6. [PubMed: 9777698]

39. Zou Y, Stastny P, Susal C, et al. Antibodies against MICA antigens and kidney-transplant rejection. N Engl J Med 2007;357(13):1293-300. [PubMed: 17898098]

40. Alachkar N, Gupta G, Montgomery RA. Angiotensin antibodies and focal segmental glomerulosclerosis. N Engl J Med 2013;368(10):971-3.

41. Mujtaba MA, Sharfuddin AA, Book BL, et al. Pre-transplant angiotensin receptor II type 1 antibodies and risk of post-transplant focal segmental glomerulosclerosis recurrence. Clin Transplant 2015;29(7):606-11. [PubMed: 25973696]

42. Delville M, Sigdel TK, Wei C, et al. A circulating antibody panel for pretransplant prediction of FSGS recurrence after kidney transplantation. Sci Transl Med 2014;6(256):256ra136.

43. Waikar SS, Betensky RA, Emerson SC, et al. Imperfect gold standards for kidney injury biomarker evaluation. J Am Soc Nephrol 2012;23(1):13-21. [PubMed: 22021710] 
44. Nankivell BJ, Alexander SI. Rejection of the kidney allograft. N Engl J Med 2010;363(15):145162. [PubMed: 20925547]

45. Halawa A The early diagnosis of acute renal graft dysfunction: a challenge we face. The role of novel biomarkers. Ann Transplant 2011;16(1):90-8. [PubMed: 21436782]

46. Williams WW, Taheri D, Tolkoff-Rubin N, et al. Clinical role of the renal transplant biopsy. Nat Rev Nephrol 2012;8(2):110-21. [PubMed: 22231130]

47. Diaz-Buxo JA, Donadio JV Jr. Complications of percutaneous renal biopsy: an analysis of 1,000 consecutive biopsies. Clin Nephrol 1975;4(6):223-7. [PubMed: 1204261]

48. Stiles KP, Yuan CM, Chung EM, et al. Renal biopsy in high-risk patients with medical diseases of the kidney. Am J Kidney Dis 2000;36(2):419-33. [PubMed: 10922324]

49. Kersnik Levart T, Kenig A, Buturovic Ponikvar J, et al. Real-time ultrasound-guided renal biopsy with a biopsy gun in children: safety and efficacy. Acta Paediatr 2001;90(12):1394-7. [PubMed: 11853335]

50. Chesney DS, Brouhard BH, Cunningham RJ. Safety and cost effectiveness of pediatric percutaneous renal biopsy. Pediatr Nephrol 1996;10(4):493-5. [PubMed: 8865250]

51. Mahoney MC, Racadio JM, Merhar GL, et al. Safety and efficacy of kidney transplant biopsy: TruCut needle vs sonographically guided biopsy gun. AJR Am J Roentgenol 1993;160(2):325-6. [PubMed: 8424343]

52. Sarwal M, Chua MS, Kambham N, et al. Molecular heterogeneity in acute renal allograft rejection identified by DNA microarray profiling. N Engl J Med 2003; 349(2):125-38. [PubMed: 12853585]

53. Suthanthiran M, Muthukumar T. Urinary-cell mRNA and acute kidney-transplant rejection. N Engl J Med 2013;369(19):1860-1. [PubMed: 24195554]

54. Nelson PJ, Krensky AM. Chemokines, chemokine receptors, and allograft rejection. Immunity 2001;14(4):377-86. [PubMed: 11336683]

55. Segerer S, Cui Y, Eitner F, et al. Expression of chemokines and chemokine receptors during human renal transplant rejection. Am J Kidney Dis 2001;37(3): 518-31. [PubMed: 11228176]

56. $\mathrm{Hu} \mathrm{H}$, Aizenstein BD, Puchalski A, et al. Elevation of CXCR3-binding chemokines in urine indicates acute renal-allograft dysfunction. Am J Transplant 2004;4(3):432-7. [PubMed: 14961998]

57. Jackson JA, Kim EJ, Begley B, et al. Urinary chemokines CXCL9 and CXCL10 are noninvasive markers of renal allograft rejection and BK viral infection. Am J Transplant 2011;11(10):2228-34. [PubMed: 21812928]

58. Hricik DE, Nickerson P, Formica RN, et al. Multicenter validation of urinary CXCL9 as a riskstratifying biomarker for kidney transplant injury. Am J Transplant 2013;13(10):2634-44 [PubMed: 23968332]

59. Schaub S, Nickerson P, Rush D, et al. Urinary CXCL9 and CXCL10 levels correlate with the extent of subclinical tubulitis. Am J Transplant 2009;9(6):1347-53. [PubMed: 19459809]

60. Rabant M, Amrouche L, Lebreton X, et al. Urinary C-X-C motif chemokine 10 independently improves the noninvasive diagnosis of antibody-mediated kidney allograft rejection. J Am Soc Nephrol 2015;26(11):2840-51. [PubMed: 25948873]

61. Halloran PF, Reeve JP, Pereira AB, et al. Antibody-mediated rejection, T cell-mediated rejection, and the injury-repair response: new insights from the Genome Canada studies of kidney transplant biopsies. Kidney Int 2014;85(2): 258-64. [PubMed: 23965521]

62. Halloran PF, Famulski KS, Reeve J. Molecular assessment of disease states in kidney transplant biopsy samples. Nat Rev Nephrol 2016;12(9):534-48. [PubMed: 27345248]

63. Halloran PF, Reeve J, Akalin E, et al. Real time central assessment of kidney transplant indication biopsies by microarrays: the INTERCOMEX Study. Am J Transplant 2017;17(11):2851-62. [PubMed: 28449409]

64. O'Connell PJ, Zhang W, Menon MC, et al. Biopsy transcriptome expression profiling to identify kidney transplants at risk of chronic injury: a multicentre, prospective study. Lancet 2016;388(10048):983-93. [PubMed: 27452608]

65. Voelkerding KV, Dames SA, Durtschi JD. Next-generation sequencing: from basic research to diagnostics. Clin Chem 2009;55(4):641-58. [PubMed: 19246620] 
66. Knight SR, Thorne A, Faro MLL. Donor-specific Cell-Free DNA as a biomarker in solid organ transplantation. A systematic review. Transplantation 2018 10.1097/TP.0000000000002482.

67. Agbor-Enoh S, Tunc I, De Vlaminck I, et al. Applying rigor and reproducibility standards to assay donor-derived cell-free DNA as a non-invasive method for detection of acute rejection and graft injury after heart transplantation. J Heart Lung Transplant 2017;36(9):1004-12. [PubMed: 28624139]

68. Schutz E, Fischer A, Beck J, et al. Graft-derived cell-free DNA, a noninvasive early rejection and graft damage marker in liver transplantation: a prospective, observational, multicenter cohort study. PLoS Med 2017;14(4):e1002286. [PubMed: 28441386]

69. Zou J, Duffy B, Slade M, et al. Rapid detection of donor cell free DNA in lung transplant recipients with rejections using donor-recipient HLA mismatch. Hum Immunol 2017;78(4):342-9. [PubMed: 28267558]

70. Gordon PM, Khan A, Sajid U, et al. An Algorithm measuring donor cell-free DNA in plasma of cellular and solid organ transplant recipients that does not require donor or recipient genotyping. Front Cardiovasc Med 2016;3:33. [PubMed: 27713880]

71. Beck J, Oellerich M, Schulz U, et al. Donor-derived cell-free DNA is a novel universal biomarker for allograft rejection in solid organ transplantation. Transplant Proc 2015;47(8):2400-3. [PubMed: 26518940]

72. Park J, Lin HY, Assaker JP, et al. Integrated kidney exosome analysis for the detection of kidney transplant rejection. ACS Nano 2017;11(11):11041-6. [PubMed: 29053921]

73. Fishman JA. Infection in solid-organ transplant recipients. N Engl J Med 2007; 357(25):2601-14. [PubMed: 18094380]

74. Hricik DE, Formica RN, Nickerson P, et al. Adverse outcomes of tacrolimus withdrawal in immune-quiescent kidney transplant recipients. J Am Soc Nephrol 2015;26(12):3114-22. [PubMed: 25925687]

75. Kasiske BL, Chakkera HA, Louis TA, et al. A meta-analysis of immunosuppression withdrawal trials in renal transplantation. J Am Soc Nephrol 2000;11(10): 1910-7. [PubMed: 11004223]

76. Schiff J, Cole E, Cantarovich M. Therapeutic monitoring of calcineurin inhibitors for the nephrologist. Clin J Am Soc Nephrol 2007;2(2):374-84. [PubMed: 17699437]

77. Hricik DE, Rodriguez V, Riley J, et al. Enzyme linked immunosorbent spot (ELI-SPOT) assay for interferon-gamma independently predicts renal function in kidney transplant recipients. Am J Transplant 2003;3(7):878-84. [PubMed: 12814480]

78. Ashoor I, Najafian N, Korin Y, et al. Standardization and cross validation of alloreactive IFNgamma ELISPOT assays within the clinical trials in organ transplantation consortium. Am J Transplant 2013;13(7):1871-9. [PubMed: 23710568]

79. Nather BJ, Nickel P, Bold G, et al. Modified ELISPOT technique-highly significant inverse correlation of post-Tx donor-reactive IFNgamma-producing cell frequencies with 6 and 12 months graft function in kidney transplant recipients. Transpl Immunol 2006;16(3-4):232-7. [PubMed: 17138059]

80. Nickel P, Presber F, Bold G, et al. Enzyme-linked immunosorbent spot assay for donor-reactive interferon-gamma-producing cells identifies T-cell presensitization and correlates with graft function at 6 and 12 months in renal-transplant recipients. Transplantation 2004;78(11):1640-6. [PubMed: 15591953]

81. Hricik DE, Augustine J, Nickerson P, et al. Interferon gamma ELISPOT testing as a risk-stratifying biomarker for kidney transplant injury: results from the CTOT-01 multicenter study. Am J Transplant 2015;15(12):3166-73. [PubMed: 26226830]

82. Sottong PR, Rosebrock JA, Britz JA, et al. Measurement of T-lymphocyte responses in wholeblood cultures using newly synthesized DNA and ATP. Clin Diagn Lab Immunol 2000;7(2):30711. [PubMed: 10702511]

83. Kowalski RJ, Post DR, Mannon RB, et al. Assessing relative risks of infection and rejection: a meta-analysis using an immune function assay. Transplantation 2006;82(5):663-8. [PubMed: 16969290] 
84. Huskey J, Gralla J, Wiseman AC. Single time point immune function assay (ImmuKnow) testing does not aid in the prediction of future opportunistic infections or acute rejection. Clin J Am Soc Nephrol 2011;6(2):423-9. [PubMed: 21088287]

85. Wang Z, Liu X, Lu P, et al. Performance of the ImmuKnow assay in differentiating infection and acute rejection after kidney transplantation: a meta-analysis. Transplant Proc 2014;46(10):334351. [PubMed: 25498049]

86. Moon HH, Kim TS, Lee S, et al. Serial ImmuKnow assay in stable kidney transplant recipients. Cent Eur J Immunol 2014;39(1):96-9. [PubMed: 26155107]

87. Ravaioli M, Neri F, Lazzarotto T, et al. Immunosuppression modifications based on an immune response assay: results of a randomized, controlled trial. Transplantation 2015;99(8):1625-32. [PubMed: 25757214]

88. He J, Li Y, Zhang H, et al. Immune function assay (ImmuKnow) as a predictor of allograft rejection and infection in kidney transplantation. Clin Transplant 2013; 27(4):E351-8. [PubMed: 23682828]

89. Kwun J, Bulut P, Kim E, et al. The role of B cells in solid organ transplantation. Semin Immunol 2012;24(2):96-108. [PubMed: 22137187]

90. Valujskikh A, Bromberg JS. Literature watch: implications for transplantation. Am J Transplant 2013;13(5):1117. [PubMed: 23621158]

91. Zachary AA, Kopchaliiska D, Montgomery RA, et al. HLA-specific B cells: I. A method for their detection, quantification, and isolation using HLA tetramers. Transplantation 2007;83(7):982-8. [PubMed: 17460571]

92. Zachary AA, Kopchaliiska D, Montgomery RA, et al. HLA-specific B cells: II. Application to transplantation. Transplantation 2007;83(7):989-94. [PubMed: 17460572]

93. Zachary AA, Lucas DP, Montgomery RA, et al. Rituximab prevents an anamnestic response in patients with cryptic sensitization to HLA. Transplantation 2013;95(5):701-4. [PubMed: 23503502]

94. Czerkinsky CC, Nilsson LA, Nygren H, et al. A solid-phase enzyme-linked immunospot (ELISPOT) assay for enumeration of specific antibody-secreting cells. J Immunol Methods 1983;65(1-2):109-21. [PubMed: 6361139]

95. Heidt S, Roelen DL, de Vaal YJ, et al. A NOVel ELISPOT assay to quantify HLA-specific B cells in HLA-immunized individuals. Am J Transplant 2012;12(6):1469-78. [PubMed: 22390272]

96. Karahan GE, de Vaal YJ, Roelen DL, et al. Quantification of HLA class II-specific memory B cells in HLA-sensitized individuals. Hum Immunol 2015;76(2-3):129-36. [PubMed: 25636565]

97. Thaunat O, Patey N, Caligiuri G, et al. Chronic rejection triggers the development of an aggressive intragraft immune response through recapitulation of lymphoid organogenesis. J Immunol 2010;185(1):717-28. [PubMed: 20525884]

98. Thaunat O, Field AC, Dai J, et al. Lymphoid neogenesis in chronic rejection: evidence for a local humoral alloimmune response. Proc Natl Acad Sci U S A 2005; 102(41):14723-8. [PubMed: 16192350]

99. Bachelet T, Couzi L, Lepreux S, et al. Kidney intragraft donor-specific antibodies as determinant of antibody-mediated lesions and poor graft outcome. Am J Transplant 2013;13(11):2855-64. [PubMed: 24102857]

100. Doshi MD, Goggins MO, Li L, et al. Medical outcomes in African American live kidney donors: a matched cohort study. Am J Transplant 2013;13(1):111-8. [PubMed: 23094818]

101. Muzaale AD, Massie AB, Wang MC, et al. Risk of end-stage renal disease following live kidney donation. JAMA 2014;311(6):579-86. [PubMed: 24519297]

102. Genovese G, Friedman DJ, Ross MD, et al. Association of trypanolytic ApoL1 variants with kidney disease in African Americans. Science 2010;329(5993): 841-5. [PubMed: 20647424]

103. Kopp JB, Smith MW, Nelson GW, et al. MYH9 is a major-effect risk gene for focal segmental glomerulosclerosis. Nat Genet 2008;40(10):1175-84. [PubMed: 18794856]

104. Ma L, Langefeld CD, Comeau ME, et al. APOL1 renal-risk genotypes associate with longer hemodialysis survival in prevalent nondiabetic African American patients with end-stage renal disease. Kidney Int 2016;90(2):389-95. [PubMed: 27157696] 
105. Kalil RS, Smith RJ, Rastogi P, et al. Late reoccurrence of collapsing FSGS after transplantation of a living-related kidney bearing APOL 1 risk variants without disease evident in donor supports the second hit hypothesis. Transplant Direct 2017;3(8):e185. [PubMed: 28795137]

106. Locke JE, Sawinski D, Reed RD, et al. Apolipoprotein L1 and chronic kidney disease risk in young potential living kidney donors. Ann Surg 2018;267(6):1161-8. [PubMed: 28187045]

107. Doshi MD, Ortigosa-Goggins M, Garg AX, et al. APOL1 genotype and renal function of black living donors. J Am Soc Nephrol 2018;29(4):1309-16. [PubMed: 29339549]

108. Young BA, Fullerton SM, Wilson JG, et al. Clinical genetic testing for APOL1: are we there yet? Semin Nephrol 2017;37(6):552-7. [PubMed: 29110763]

109. Wu H, Malone AF, Donnelly EL, et al. Single-cell transcriptomics of a human kidney allograft biopsy specimen defines a diverse inflammatory response. J Am Soc Nephrol 2018;29(8):206980. [PubMed: 29980650]

110. Sarwal MM, Benjamin J, Butte AJ, et al. Transplantomics and biomarkers in organ transplantation: a report from the first international conference. Transplantation 2011;91(4):37982. [PubMed: 21278631] 


\section{KEY POINTS}

- $\quad$ Biomarkers in solid organ transplantation are critical tools in assessing immunologic risks and preventing graft rejection.

- A paucity of sensitive and specific biomarkers hinders outcome of both the graft and the recipient.

- Number of novel biomarkers are being introduced; understanding the biological concept and methods can guide effective application of these powerful tools. 